\title{
Impact of Research Performance and Perception on Ranking of Universities-A study based on NIRF 2019
}

\author{
A.N. Parameswaran ${ }^{1}$, Ajit M. Hebbale ${ }^{2}$, S.M. Vidya ${ }^{3}$, T. P. M. Pakkala ${ }^{4}$ \\ ${ }^{1}$ Department of Civil Engineering, NMAM Institute of Technology, Nitte, Karnataka, India. \\ ${ }^{1}$ Director, Industry-Institute Collaboration (IIC), NMAM Institute of Technology, Nitte, Karnataka, India. \\ ${ }^{2}$ Department of Mechanical Engineering, NMAM Institute of Technology, Nitte, Karnataka, India. \\ ${ }^{3}$ Department of Biotechnology, NMAM Institute of Technology, Nitte, Karnataka, India. \\ ${ }^{4}$ Justice K.S. Hegde Institute of Management, Nitte, Karnataka, India. \\ 1director.iic@nitte.edu.in
}

\begin{abstract}
Research performance in university is an important criterion in ranking. The study aims to understand the significance of research performance in university rankings based on the National Institutional Ranking Framework (NIRF) of India 2019. The study analyses Indian rankings 2019 of universities with respect to Research and Professional Practices (RPP) score and evaluates the relationship between RPP and Perception (PR) for top-ranked 100 universities. This study has established interdependency between RPP and PR and it is found that both are highly significant in university ranking process.
\end{abstract}

Keywords: NIRF 2019, University rank, Research and Professional Practices, Perception.

\section{Introduction}

The Ministry of Human Resource Development (MHRD) is responsible for the development of human resources in India and the enhancement of basic infrastructure both in terms of policy and planning and in specific tends to expand access and quality

\section{A.N. Parameswaran}

Department of Civil,

Engineering, NMAM Institute of Technology, Nitte, Karnataka, director.iic@nitte.edu.in improvement in higher education. According to University Grants Commission (UGC), as on 31st March 2019, the total number of universities in India is about 907; among which there are 399 state universities, 126 Deemed to be universities, 48 central universities, and 334 private universities. In this connection on 29th September 2015, NIRF was approved by MHRD to rank higher educational institutions in the country to promote competitive excellence based on objective criteria. It covers broad parameters viz., Teaching, Learning, and Resources (TLR), RPP, Graduate Outcomes (GO), Outreach, and Inclusivity (OI) and PR. From the inception of NIRF, there are changes in parameters and subparameters to strengthen the ranking system to make it robust and effective. Ranking parameters, sub-parameters, relative score, weightage, and weighted score are as depicted in the following table.

\section{Review of Literature}

Several studies have evaluated the main indicators of the ranking system in the field of higher education. Some of the following studies have proved the role of research performance in the ranking process. Buelaet. al., 2007 in a research article on comparative study on international academic ranking of universities indicated that four selected international rankings included an indicator for quality of research which was the most significant indicator of international university ranking. Gagan Pratap and Gupta 2009 used a new performance index to discuss how the ranking of Indian universities is based on their 
Table 1: Parameters and Sub parameters of University Ranking (NIRF 2018)

\begin{tabular}{|c|c|c|c|}
\hline Parameters / Sub-Parameters & Score & Weightage & $\begin{array}{l}\text { Weighted } \\
\text { Score }\end{array}$ \\
\hline $\begin{array}{l}\text { 1. Teaching-Learning and Resources (TLR) } \\
\text { - Students Strength including Doctoral Students } \\
\text { - Faculty-Student Ratio } \\
\text { - Combined Metric for Faculty with PhD and } \\
\text { Experience } \\
\text { - Financial Resources and their Utilization }\end{array}$ & 100 & 0.30 & 30 \\
\hline $\begin{array}{l}\text { 2. Research and Professional Practice (RPP) } \\
\text { - Combined Metric for Publications } \\
\text { - Combined Metric for Quality of Publications } \\
\text { - IPR and Patents: Published and Granted } \\
\text { - Footprint of Projects and Professional Practice }\end{array}$ & 100 & 0.30 & 30 \\
\hline $\begin{array}{l}\text { 3. Graduation Outcome (GO) } \\
\text { - Metric for University Examinations } \\
\text { - Metric for Number of PhD Students Graduated }\end{array}$ & 100 & 0.20 & 20 \\
\hline $\begin{array}{l}\text { 4. Outreach and Inclusivity (OI) } \\
\text { - Percentage of Students from Other States / } \\
\text { Countries (Region Diversity) } \\
\text { - Percentage of Women (Women Diversity) } \\
\text { - Economically and Socially Challenged Students } \\
\text { - Facilities for Physically Challenged Students }\end{array}$ & 100 & 0.10 & 10 \\
\hline $\begin{array}{l}\text { 5. Perception (PR) } \\
\text { - Peer Perception: Academic Peers and Employers }\end{array}$ & 100 & 0.10 & 10 \\
\hline \multicolumn{3}{|l|}{ Total Weighted Score (TWS) } & 100 \\
\hline
\end{tabular}

research output and quality. In 2010, analysis was made by Gupta on Indian universities ranking and highlighted the importance of publications and citations in ranking. 2012 studies of Huang calculated the ranking of universities all over the world using their h-index scores to measure research performance. Bagalkoti and Sangam, 2012 studied ranking of Indian universities accredited by NAAC with respect to research publication data. Comparison of India and China based on academic and research metrics was carried out by K.S. Reddy (2016) and emphasized upon various citation criteria's. Sheeja et al. 2018 stressed the importance of scholarly communication and institutional ranking; a study based on NIRF and established a significant correlation between scholarly communication and institutional ranking. Analytical results of research publication data by Sumitet et al. 2017 provided useful account of research performance of IITs. According to India Rankings report 2019, the top-rated 100 universities accounted for $69.63 \%$ research publications \&
79.74\% of Highly Cited Publications (HCP) out of the 303 participating \& eligible universities. Moreover, the faculty with doctoral qualification isconcentrated in top-rated 50/100 engineering institutions; remaining institutions have very few faculty members with doctoral degrees. In this context, our study is aiming to analyze the relationship between research and professional practice\&perception and their influence on the overall ranking based on NIRF-2019 of India.

\section{Objectives of the Study}

1. To understand the parameters and sub-parameters of Indian Rankings 2019 for universities.

2. To study universities in Indian Rankings 2019 with respect to its RPP \& PR score.

3. To analyze the relationship between RPP and PR score with reference to university ranking.

4. To suggest methods to improve the Research \& Professional Practice score.

\section{Methodology}

The data for the study on the impact of research performance and perception on the ranking of universities by Indian ranking 2019 is primary and the data for the study was collected from the NIRF portal for 100 ranked universities which included both public and private universities. Dependence and interrelations was studied through correlation and regression analysis. These analyses were carried out with the help of statistical software R programming. All the tests are tested at a 5\% level of significance. Pvalues less than 0.05 indicated that the test values were significant. Whenever these testing values were very highly significant the corresponding $p$-values became negligibly small and sometimes it was zero.

Table 2: Study on Universities in Indian Ranking 2019 with RPP rank and PR score (NIRF 2019)

\begin{tabular}{|l|l|c|c|c|c|}
\hline \multicolumn{1}{|c|}{ University } & \multicolumn{1}{|c|}{ State } & $\begin{array}{c}\text { NIRF } \\
\text { Rank }\end{array}$ & $\begin{array}{c}\text { RPP } \\
\text { Rank }\end{array}$ & $\begin{array}{c}\text { RPP } \\
\text { Score }\end{array}$ & $\begin{array}{c}\text { PR } \\
\text { Score }\end{array}$ \\
\hline $\begin{array}{l}\text { Indian Institute of Science } \\
\text { Bengaluru }\end{array}$ & Karnataka & 1 & 1 & 89.24 & 100 \\
\hline Jadavpur University & West Bengal & 6 & 2 & 54.89 & 51.83 \\
\hline Anna University & Tamil Nadu & 7 & 3 & 54.1 & 62.72 \\
\hline University of Delhi & Delhi & 13 & 4 & 53.79 & 41.11 \\
\hline
\end{tabular}




\begin{tabular}{|c|c|c|c|c|c|}
\hline Institute of Chemical Technology & Maharashtra & 15 & 5 & 48.4 & 20.28 \\
\hline $\begin{array}{l}\text { Vellore Institute of } \\
\text { Technology }\end{array}$ & Tamil Nadu & 19 & 6 & 47.63 & 35.31 \\
\hline Calcutta University & West Bengal & 5 & 7 & 47.1 & 37.39 \\
\hline Banaras Hindu University & Uttar Pradesh & 3 & 8 & 46.48 & 47.28 \\
\hline Bharathiar University & Tamil Nadu & 14 & 9 & 45.04 & 31.2 \\
\hline Panjab University & Chandigarh & 21 & 10 & 44.82 & 27.09 \\
\hline $\begin{array}{l}\text { Savitribai Phule Pune } \\
\text { University }\end{array}$ & Maharashtra & 10 & 11 & 44.42 & 16.55 \\
\hline University of Hyderabad & Telangana & 4 & 12 & 43.78 & 36.71 \\
\hline Amrita VishwaVidyapeetham & Tamil Nadu & 8 & 13 & 43.77 & 31.01 \\
\hline Jawaharlal Nehru University & Delhi & 2 & 14 & 41.85 & 55.27 \\
\hline $\begin{array}{l}\text { Manipal Academy of Higher } \\
\text { Education }\end{array}$ & Karnataka & 9 & 15 & 38.31 & 30.21 \\
\hline $\begin{array}{l}\text { Thapar Institute of } \\
\text { Engineering and Technology }\end{array}$ & Punjab & 27 & 16 & 36.3 & 10.24 \\
\hline Aligarh Muslim University & Uttar Pradesh & 11 & 17 & 35.38 & 18.46 \\
\hline $\begin{array}{l}\text { Birla Institute of Technology \& } \\
\text { Science }\end{array}$ & Rajasthan & 23 & 18 & 34.14 & 34.41 \\
\hline University of Madras & Tamil Nadu & 20 & 19 & 33.28 & 30.01 \\
\hline $\begin{array}{l}\text { Shanmugha Arts Science } \\
\text { Technology \& Research } \\
\text { Academy }\end{array}$ & Tamil Nadu & 40 & 20 & 32.38 & 6.86 \\
\hline JamiaMilliaIslamia & Delhi & 12 & 21 & 32.04 & 14.26 \\
\hline Tezpur University & Assam & 29 & 22 & 30.1 & 15.71 \\
\hline JamiaHamdard & Delhi & 18 & 23 & 29.92 & 6.86 \\
\hline Birla Institute of Technology & Jharkhand & 59 & 24 & 29.47 & 23.47 \\
\hline Guru Nanak Dev University & Punjab & 55 & 25 & 29.38 & 5.8 \\
\hline Bharathidasan University & Tamil Nadu & 60 & 26 & 29.05 & 24.17 \\
\hline Amity University & Uttar Pradesh & 58 & 27 & 28.3 & 7.22 \\
\hline Madurai Kamaraj University & Tamil Nadu & 45 & 28 & 28.11 & 20.28 \\
\hline $\begin{array}{l}\text { Sathyabama Institute of } \\
\text { Science and Technology }\end{array}$ & Tamil Nadu & 41 & 29 & 27.15 & 2.41 \\
\hline Mahatma Gandhi University & Kerala & 30 & 30 & 26.97 & 3.58 \\
\hline $\begin{array}{l}\text { Cochin University of Science and } \\
\text { Technology }\end{array}$ & Kerala & 65 & 31 & 26.88 & 14.84 \\
\hline Pondicherry University & Pondicherry & 48 & 32 & 26.63 & 19.25 \\
\hline $\begin{array}{l}\text { International Institute of } \\
\text { Information Technology }\end{array}$ & Telangana & 82 & 33 & 26.62 & 15.99 \\
\hline $\begin{array}{l}\text { SRM Institute of Science and } \\
\text { Technology }\end{array}$ & Tamil Nadu & 32 & 34 & 26.51 & 14.26 \\
\hline
\end{tabular}




\begin{tabular}{|c|c|c|c|c|c|}
\hline VisvaBharati & West Bengal & 37 & 35 & 26.07 & 11.52 \\
\hline $\begin{array}{l}\text { King George`s Medical } \\
\text { University }\end{array}$ & Uttar Pradesh & 25 & 36 & 25.85 & 5.8 \\
\hline $\begin{array}{l}\text { HomiBhabha National } \\
\text { Institute }\end{array}$ & Maharashtra & 17 & 37 & 25.24 & 4.33 \\
\hline Osmania University & Telangana & 26 & 38 & 24.95 & 9.26 \\
\hline $\begin{array}{l}\text { Delhi Technological } \\
\text { University }\end{array}$ & Delhi & 47 & 39 & 24.33 & 19.51 \\
\hline Sri Venkateswara University & $\begin{array}{l}\text { Andhra } \\
\text { Pradesh }\end{array}$ & 48 & 40 & 23.6 & 6.51 \\
\hline Andhra University & $\begin{array}{l}\text { Andhra } \\
\text { Pradesh }\end{array}$ & 16 & 41 & 23.16 & 14.55 \\
\hline Alagappa University & Tamil Nadu & 28 & 42 & 22.18 & 26.65 \\
\hline Siksha `O’ Anusandhan & Odisha & 24 & 43 & 21.17 & 20.02 \\
\hline The University of Burdwan & West Bengal & 89 & 44 & 20.96 & 2.41 \\
\hline Periyar University & Tamil Nadu & 68 & 45 & 20.74 & 19.25 \\
\hline Kalyani University & West Bengal & 91 & 46 & 20.64 & 4.7 \\
\hline $\begin{array}{l}\text { Punjab Agricultural } \\
\text { University }\end{array}$ & Punjab & 51 & 47 & 19.74 & 3.19 \\
\hline $\begin{array}{l}\text { KoneruLakshmaiah } \\
\text { Education Foundation } \\
\text { University }\end{array}$ & $\begin{array}{l}\text { Andhra } \\
\text { Pradesh }\end{array}$ & 50 & 48 & 19.07 & 3.58 \\
\hline $\begin{array}{l}\text { Guru Gobind Singh } \\
\text { Indraprastha University }\end{array}$ & Delhi & 66 & 49 & 18.96 & 3.58 \\
\hline Kerala University & Kerala & 22 & 50 & 18.84 & 8.59 \\
\hline University of Kashmir & $\begin{array}{l}\text { Jammu\&Kash } \\
\text { mir }\end{array}$ & 53 & 51 & 18.33 & 1.63 \\
\hline $\begin{array}{l}\text { The Gandhigram Rural } \\
\text { Institute }\end{array}$ & Tamil Nadu & 75 & 52 & 18.2 & 6.15 \\
\hline Mysore University & Karnataka & 54 & 53 & 18.15 & 4.7 \\
\hline $\begin{array}{l}\text { Kalinga Institute of Industrial } \\
\text { Technology }\end{array}$ & Odisha & 31 & 54 & 18.1 & 14.55 \\
\hline Gauhati University & Assam & 42 & 55 & 18.08 & 9.59 \\
\hline $\begin{array}{l}\text { Bharath Institute of Higher } \\
\text { Education \& Research }\end{array}$ & Tamil Nadu & 36 & 56 & 17.76 & 3.19 \\
\hline $\begin{array}{l}\text { Saveetha Institute of Medical } \\
\text { and Technical Sciences }\end{array}$ & Tamil Nadu & 43 & 57 & 17.64 & 0 \\
\hline Mumbai University & Maharashtra & 81 & 58 & 17.1 & 7.91 \\
\hline $\begin{array}{l}\text { Sri Ramachandra Inst. of } \\
\text { Higher Education and } \\
\text { Research }\end{array}$ & Tamil Nadu & 33 & 59 & 16.57 & 6.15 \\
\hline University of Jammu & $\begin{array}{l}\text { Jammu\&Kash } \\
\text { mir }\end{array}$ & 74 & 60 & 16.51 & 2.02 \\
\hline
\end{tabular}




\begin{tabular}{|c|c|c|c|c|c|}
\hline Calicut University & Kerala & 64 & 61 & 16.46 & 7.22 \\
\hline $\begin{array}{l}\text { JSS Academy of Higher } \\
\text { Education and Research }\end{array}$ & Karnataka & 34 & 62 & 15.74 & 10.24 \\
\hline $\begin{array}{l}\text { G. B. Pant Universtiy of } \\
\text { Agriculture and Technology }\end{array}$ & Uttarakhand & 38 & 63 & 15.49 & 5.44 \\
\hline $\begin{array}{l}\text { Karunya Institute of Technology } \\
\text { and Sciences }\end{array}$ & Tamil Nadu & 92 & 64 & 15.1 & 12.76 \\
\hline $\begin{array}{l}\text { ManonmaniamSundaranar } \\
\text { University }\end{array}$ & Tamil Nadu & 93 & 65 & 14.89 & 8.25 \\
\hline North Eastern Hill University & Meghalaya & 39 & 66 & 14.53 & 6.51 \\
\hline Goa University & Goa & 93 & 67 & 14.46 & 1.63 \\
\hline Shiv Nadar University & Uttar Pradesh & 52 & 68 & 14.05 & 6.15 \\
\hline $\begin{array}{l}\text { MaharshiDayanand } \\
\text { University }\end{array}$ & Haryana & 90 & 69 & 13.91 & 2.41 \\
\hline Central University of Punjab & Punjab & 95 & 70 & 13.62 & 7.91 \\
\hline Alagappa University & Tamil Nadu & 28 & 42 & 22.18 & 26.65 \\
\hline Siksha 'O’ Anusandhan & Odisha & 24 & 43 & 21.17 & 20.02 \\
\hline The University of Burdwan & West Bengal & 89 & 44 & 20.96 & 2.41 \\
\hline Periyar University & Tamil Nadu & 68 & 45 & 20.74 & 19.25 \\
\hline Kalyani University & West Bengal & 91 & 46 & 20.64 & 4.7 \\
\hline $\begin{array}{l}\text { Punjab Agricultural } \\
\text { University }\end{array}$ & Punjab & 51 & 47 & 19.74 & 3.19 \\
\hline $\begin{array}{l}\text { KoneruLakshmaiah } \\
\text { Education Foundation } \\
\text { University }\end{array}$ & $\begin{array}{l}\text { Andhra } \\
\text { Pradesh }\end{array}$ & 50 & 48 & 19.07 & 3.58 \\
\hline $\begin{array}{l}\text { Guru Gobind Singh } \\
\text { Indraprastha University }\end{array}$ & Delhi & 66 & 49 & 18.96 & 3.58 \\
\hline Kerala University & Kerala & 22 & 50 & 18.84 & 8.59 \\
\hline University of Kashmir & $\begin{array}{l}\text { Jammu\&Kash } \\
\text { mir }\end{array}$ & 53 & 51 & 18.33 & 1.63 \\
\hline $\begin{array}{l}\text { The Gandhigram Rural } \\
\text { Institute }\end{array}$ & Tamil Nadu & 75 & 52 & 18.2 & 6.15 \\
\hline Mysore University & Karnataka & 54 & 53 & 18.15 & 4.7 \\
\hline $\begin{array}{l}\text { Kalinga Institute of Industrial } \\
\text { Technology }\end{array}$ & Odisha & 31 & 54 & 18.1 & 14.55 \\
\hline Gauhati University & Assam & 42 & 55 & 18.08 & 9.59 \\
\hline $\begin{array}{l}\text { Bharath Institute of Higher } \\
\text { Education \& Research }\end{array}$ & Tamil Nadu & 36 & 56 & 17.76 & 3.19 \\
\hline $\begin{array}{l}\text { Saveetha Institute of Medical } \\
\text { and Technical Sciences }\end{array}$ & Tamil Nadu & 43 & 57 & 17.64 & 0 \\
\hline Mumbai University & Maharashtra & 81 & 58 & 17.1 & 7.91 \\
\hline $\begin{array}{l}\text { Sri Ramachandra Inst. of } \\
\text { Higher Education and Research }\end{array}$ & Tamil Nadu & 33 & 59 & 16.57 & 6.15 \\
\hline
\end{tabular}




\begin{tabular}{|l|l|c|c|c|c|}
\hline University of Jammu & $\begin{array}{l}\text { Jammu\& } \\
\text { Kashmir }\end{array}$ & 74 & 60 & 16.51 & 2.02 \\
\hline Calicut University & Kerala & 64 & 61 & 16.46 & 7.22 \\
\hline $\begin{array}{l}\text { JSS Academy of Higher } \\
\text { Education and Research }\end{array}$ & Karnataka & 34 & 62 & 15.74 & 10.24 \\
\hline $\begin{array}{l}\text { G. B. Pant Universtiy of } \\
\text { Agriculture and Technology }\end{array}$ & Uttarakhand & 38 & 63 & 15.49 & 5.44 \\
\hline $\begin{array}{l}\text { Karunya Institute of Technology } \\
\text { and Sciences }\end{array}$ & Tamil Nadu & 92 & 64 & 15.1 & 12.76 \\
\hline $\begin{array}{l}\text { ManonmaniamSundaranar } \\
\text { University }\end{array}$ & Tamil Nadu & 93 & 65 & 14.89 & 8.25 \\
\hline North Eastern Hill University & Meghalaya & 39 & 66 & 14.53 & 6.51 \\
\hline Goa University & Goa & 93 & 67 & 14.46 & 1.63 \\
\hline Shiv Nadar University & Uttar Pradesh & 52 & 68 & 14.05 & 6.15 \\
\hline $\begin{array}{l}\text { MaharshiDayanand } \\
\text { University }\end{array}$ & Haryana & 90 & 69 & 13.91 & 2.41 \\
\hline Central University of Punjab & Punjab & 95 & 70 & 13.62 & 7.91 \\
\hline $\begin{array}{l}\text { Professor } \\
\text { JayashankarTelangana State } \\
\text { Agricultural University }\end{array}$ & Telangana & 79 & 99 & 1.71 & 1.63 \\
\hline $\begin{array}{l}\text { Meenakshi Academy of } \\
\text { Higher Education and Research }\end{array}$ & Tamil Nadu & 100 & 100 & 1.62 & 0 \\
\hline
\end{tabular}

\section{Data analysis and findings}

The RPP rank or RPP score are very influential component in the NIRF ranking of Universities. The strong correlation of 0.7702 between NIRF ranking and RPP ranking indicates a strong relationship between them. Alternatively, if we consider the correlation between NIRF ranking and RPP score, it is also of similar strength, with correlation of -0.76072 . The negative sign is because ranking are given in the opposite order. Hence, it can be concluded that concentrating on RPP score is very important, as its influence on NIRF ranking is very strong.

Next, it is interesting to study how PR scores are influenced by RPP score. The important part of the study here is to examine the relationship between these two scores. From the study, it can be concluded that if RPP scores are improved then it automatically improves PR score. It is empirically established that the relationship between RPP and PR is strong. In case of public sector Universities the correlation between them is 0.88 which is very strong and its $p$ - value of significance of the correlation is measured as 0 for the corresponding $\mathrm{Z}$ statistic value 14.5798 . Since a strong relation is clear, an empirical linear relationship is established to emphasize this. Hence, the trend of PR based on RPP is established using regression analysis and it is $\mathrm{PR}=-8.296+0.981$, RPP the strength of the relationship can be seen through the $\mathrm{p}$-value of the significance of regression which is less than $2 \times 10-16$. This indicates that the regression coefficient is very highly significant. The Figure 1 gives the chart of PR and RPP and the trend line of PR based on RPP in public sector universities.

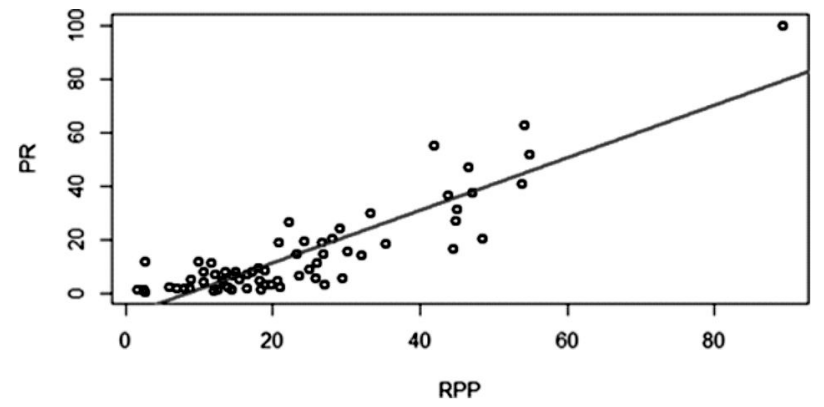

Fig.1: Relationship between PR and RPP for public sector 
The same type of analysis is carried out for the private sector universities. The correlation between RPP and $\mathrm{PR}$ is 0.7527304 and its significance is measured through the $\mathrm{p}$-value of $2.61 \times 10-11$ and the $\mathrm{Z}$ statistic value is 6.667086 . Since PR is very much dependent on RPP ifRPP score increases then PR score is also likely to increase. The linear relationship relation exhibited through regression is found to be $P R=$ $2.7337+0.6403$ RPP. Its significance measured through a p-value of $1.19 \times 10-7$. Figure 2 presents the trend of PR based on RPP is private universities.

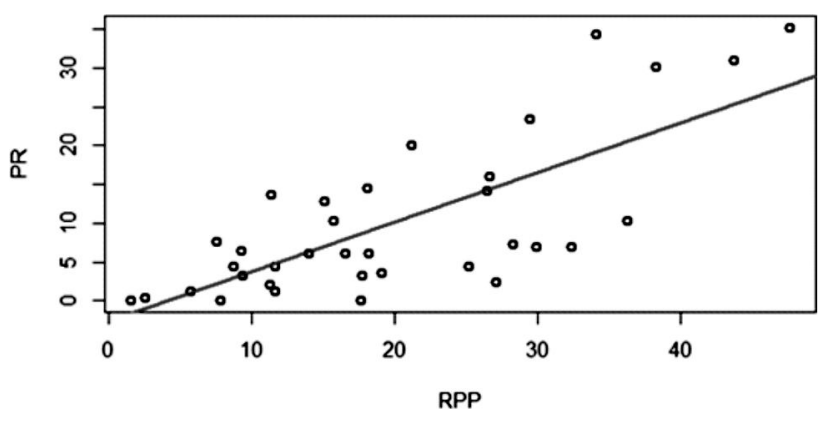

Fig. 2: Relationship between PRand RPP for the private sector.

The important findings are 1) RPP score has greater influence on NIRF ranking 2) Strong correlation exists between RPP score and PR score. The above findings clearly show the universities have to concentrate on RPP which calls for a culture shift among faculty members from core teaching to research and to establish an exclusive directorate for research to improve the number research publications per faculty \& the quality of publications, number of patents, consultancy, and funded research projects.

Suggestions to improve the Research \& Professional Practice Score:

The improvement in RPP score can be done through supportive research policies \& strategies with short term, midterm, and long term goals.

The focus can be on the suggested five steps approach:

(i) development of human resource for research and consultancy by encouraging the existing PG holders to pursue Doctoral Programme and restructuring the recruitment policy to recruit quality doctoral fellows, (ii) training of HR for research and consultancy,

(iii) launching HR for research and consultancy, (iv) monitoring $\mathrm{HR}$ for research and consultancy and

(v) special encouragement for achievers.

As the performance in RPP is equally important for the Affiliating institutions and Autonomous institutions the institutions can conduct regular workshops and seminars on research tools and research paper writing \& can arrange author workshops with the publishers. Moreover to introduce the electronic resources the workshops on databases and e-journals can be organized.

\section{Conclusion}

The study evaluated the role of RPP and PR in institutional ranking. It was found that both are very important factors that influence the overall ranking of any university. Statistically very strong correlation exists between university rank and RPP ranks. Hence RPP influences NIRF ranking. It is also found that RPP is also influencing perception. Therefore if the RPP increases, university ranking also increases as research also influences the perception of the university. Hence it can be concluded that concentrating on the RPP score is very important, as its influence on the NIRF ranking is very strong and if RPP scores are improved then it automatically improves PR score.

As RPP is the most complex factor and requires a dedicated research group to improve ranking in universities, the directorate of research in coordination with library and information science professionals has to increase the quality research output among faculty members and to implement the suggested five steps approach.

\section{References}

[1] Buela-Casal, G., Gutiérrez-Martínez, O., Bermúdez-Sánchez, M. P., \&Vadillo- Muñoz, O. (2007) Comparative study of international academic rankings of universities. Scientometrics, 71(3), 349-365.

[2] Gangan Prathap, B.M. Gupta (2009) Ranking of Indian universities for their research output and quality using a new performance index Current science 97(6):751-752

[3] Gupta, B. M. (2010) Ranking and performance of Indian Universities based on publication and 
citation data. Indian Journal of Science and Technology, 3(7), 837-843.

[4] Huang, M. H. (2012) Exploring the h-index at the institutional level: A practical application in world university rankings. Online Information Review, 36(4), 534-547.

[5] V.T.Bagalkoti, S.L. Sangam. (2012) Ranking of NAAC Accredited Indian Universities, National Conference on Scientometrics, 317-330.

[6] K.S.Reddy, EnXie, Qingqing Tang. (2016) Higher education, high-impact research, and world university rankings: A case of India and comparison with China Pacific Science Review B: Humanities and Social Sciences, 2(1), 1-21.

[7] Sheeja N.K., Susan Mathew K., Surendran Cherukodan, (2018) Impact of scholarly output on university ranking, Global Knowledge, Memory and Communication, Vol. 67 Issue: 3, pp.154-165, https://doi.org/10.1108/GKMC-112017-0087.

[8] Sumit Kumar Bansal, Vivek Kumar Singh, Aparna Basu, and Pranab Kumar Muhuri. (2017) Research performance of Indian Institutes of Technology. Current Science, 112 (5) 923-932.

[9] Indian Rankings 2019 Report https://nirfcdn.azureedge.net/2019/flipbook/ind ex.html $\# \mathrm{p}=20$

[10] https://www.nirfindia.org/2018/Ranking2018. html

[11]https://www.nirfindia.org/2019/Ranking2019.ht $\mathrm{ml}$ 